Open access article, license CC BY-NC-ND

Issue IV, 22 November 2021

e-ISSN 2707-9481

Institute of Metallurgy and Ore Beneficiation, Satbayev University, Almaty, Kazakhstan

ISBN 978-601-323-252-2

https://doi.org/10.31643/2021.07

Dyussenova Symbat Berikkalikyzy - PhD, researcher.

JSC "Institute of Metallurgy and Ore Beneficiation", Satbayev University Almaty, Kazakhstan. Email: s.dyussenova@satbayev.university ORCID ID: 0000-0002-1990-3678.
El-Amir, Ahmed A. M. - PhD, researcher. Central Metallurgical R\&D Institute (CMRDI) 1-Elfilizat street, El-Tabbin, Helwan, Cairo, Egypt

Email: elamirahmed.ahmed@gmail.com ORCID ID: 0000-0003-2006-5840.

\title{
Research and development of a comprehensive technology for processing kaolinite clays in Kazakhstan
}

\begin{abstract}
In the Republic of Kazakhstan, the most promising are kaolinite clays of the Alekseevsky deposit. For effective processing of clays, it is necessary to develop special methods of processing, since satisfactory results were not achieved when using standard methods of gravity processing. The article provides the results of studies of the effect of preliminary chemical activation on the yield of the kaolinite fraction during gravitational processing. Previously, the method of preliminary chemical activation of raw materials in a solution of sodium bicarbonate has proven itself well in the processing of various mineral raw materials. It is determined that as a result of preliminary chemical activation, changes in the phase composition occurred. The dependence of the yield of the kaolinite fraction on the temperature of chemical activation, duration, and the ratio of W:T and the concentration of the sodium bicarbonate solution. Based on the results obtained, a technology for the complex processing of kaolinite clays has been developed, which provides for the preliminary chemical activation of the feedstock at the beginning of the process, which will effectively isolate high-quality kaolinite and quartz products, which will significantly reduce the flow of materials entering for sintering. As a result of activation, the phase composition of the kaolinite fraction has changed: the percentage of the kaolinite fraction has decreased; new phases of muscovite and sodium aluminosilicate appeared; the amount of quartz increased.
\end{abstract}

Keywords: kaolinite, quartz, silicon module, chemical activation, chemical processing, technology.

Cite this article as: Dyussenova S.; El-Amir, Ahmed A. M. (2021). Research and development of a comprehensive technology for processing kaolinite clays in Kazakhstan. Challenges of Science. Issue IV, 2021, pp. 48-54. https://doi.org/10.31643/2021.07

\section{Introduction}

The Pavlodar Aluminum Smelter (PAZ), the only alumina producer in the Republic of Kazakhstan, uses low-quality bauxites from the Krasnooktyabrsk deposit located in the Kostanay region, with a low flint modulus and high iron and carbonate contents $[1,2]$. Existing bauxite reserves can be enough to operate PAZ at existing capacities for not more than 15 years, therefore, it is relevant to the search for alternative raw materials sources of alumina, one of which can be kaolinite ores; the world reserves are estimated at 16 billion tons [3]. Modern mining and processing of kaolinite raw materials have an established infrastructure, are provided with raw materials and in the future can be adapted to the production of alumina and by-products [4].

The characteristics of the raw materials are of paramount importance when selecting the optimal technological process for processing kaolinite clays, which determine the theoretical yield of alumina, the consumption of reagents in key technological operations and the amount of sludge to be further processed, which should maximally meet the capabilities and interests of the respective region [5]. 
By now, a significant number of methods for processing kaolins and kaolinite clays are known and continue to be improved, among which acid technologies are historically significant. Their disadvantages are the formation of hard-to-filter finely dispersed sediments and the use of expensive acid-resistant materials and equipment [6-9].

The technology of autoclave opening in the medium of high-modulus aluminate solutions with the precipitation of silica in the form of ferrous hydro-garnets or sodium-calcium hydrosilicate $\left(\mathrm{Na}_{2} \mathrm{O} \cdot 2 \mathrm{CaO} \cdot 2 \mathrm{SiO}_{2} \cdot \mathrm{H}_{2} \mathrm{O}\right)$ is of considerable interest for the processing of kaolinite clays [5]. The undoubted advantage of this method is its versatility and the possibility of using the hydrometallurgical process for processing high-silicon raw materials of various nature. Additionally, it is distinguished by the significant complexity of the technological scheme and its hardware design, which has ruled out the industrial implementation of this method until now.

The most industrially developed method is the technology of sintering kaolin raw materials with soda and limestone added in a ratio based on the following stoichiometry [10]:

$\mathrm{Al}_{2} \mathrm{O}_{3} \cdot 2 \mathrm{SiO}_{2} \cdot 2 \mathrm{H}_{2} \mathrm{O}+4 \mathrm{CaCO}_{3}+\mathrm{Na}_{2} \mathrm{CO}_{3}=2 \mathrm{NaAlO}_{2}+2\left(2 \mathrm{CaO} \cdot \mathrm{SiO}_{2}\right)+2 \mathrm{H}_{2} \mathrm{O}+5 \mathrm{CO}_{2}$

This stoichiometry makes it possible to determine the mass of the charge, as well as to estimate the consumption of reagents and the yield of sludge, which corresponds to the composition of calcium orthosilicate with high accuracy.

\section{Methods}

X-ray fluorescence analysis was performed on a wave dispersion spectrometer Venus 200 (PANalyical B.V., Holland).

Chemical analysis of the samples was carried out on an optical emission spectrometer with inductively coupled plasma Optima 2000 DV (Perkin Elmer, USA).

Semi-quantitative X-ray phase analysis was performed on a D8 Advance (BRUKER) diffractometer using copper $\mathrm{Cu}-\mathrm{K \alpha}$ radiation at an accelerating voltage of $36 \mathrm{kV}$ and a current of $25 \mathrm{~mA}$.

Thermal analysis of the provided sample was carried out using a simultaneous thermal analysis instrument STA 449 F3 Jupiter.

Chemical activation of kaolinite clays was carried out in a solution containing from 40 to $120 \mathrm{~g} / \mathrm{dm}^{3}$ $\mathrm{NaHCO}_{3}$ at the ratio $\mathrm{L}: \mathrm{T}=2-10.0$ and temperatures of $90-230^{\circ} \mathrm{C}$ using a thermostated installation with 6 autoclaves rotating through the head with a working volume of $250 \mathrm{~cm}^{3}$, duration of activation ranged from 30 to 300 minutes. The maximum content of sodium hydrocarbonate in the solution was $120 \mathrm{~g} / \mathrm{dm}^{3}$, taking into account its solubility limit.

\section{Results and discussion}

The raw product was a representative sample of kaolinite clay from the Alekseevskiy deposit provided by company Arai pro LLP.

The chemical composition of the clay sample, wt. \%: $\mathrm{Al}_{2} \mathrm{O}_{3}-26.9 ; \mathrm{SiO}_{2}-56.6 ; \mathrm{Fe}_{2} \mathrm{O}_{3}-0.537 ; \mathrm{Na}_{2} \mathrm{O}-$ $0.07 ; \mathrm{SO}_{3}-0.028 ; \mathrm{K}_{2} \mathrm{O}-1.31$; LOI 14.555 , silicon module $\left(\mu_{\mathrm{si}}\right)-0.47$. Appearance: free-flowing whitish sand, density $2.06 \mathrm{~g} / \mathrm{cm}^{3}$, bulk density $1.36 \mathrm{~kg} / \mathrm{cm}^{3}$, average grain size $2 \mathrm{~mm}$.

$\mathrm{X}$-ray phase analysis of a clay sample is presented as, \%: kaolinite 31.4 , muscovite 1.1 , and quartz 67.5.

According to thermal analysis, the kaolinite phase appears with endothermic effects $(-) 167.8^{\circ} \mathrm{C},(-)$ $566.6^{\circ} \mathrm{C}$, and exothermic effects $(+) 993.8^{\circ} \mathrm{C}$. The endothermic effect with an extremum at $575^{\circ} \mathrm{C}$ on the DTA curve, as well as endothermic effects with extrema at $539.8{ }^{\circ} \mathrm{C}, 555.9{ }^{\circ} \mathrm{C}$ on the dDTA curve, are associated with the manifestation of dehydration of aluminum hydroxides - boehmite, diaspora with varying degrees of grinding. The combination of the endothermic effect with an extremum at $167.8^{\circ} \mathrm{C}$ and an exothermic effect with a peak at $993.8^{\circ} \mathrm{C}$ on the DTA curve is associated with the manifestation of the clay mineral allophan - $\mathrm{mAl}_{2} \mathrm{O}_{3} \mathrm{nSiO}_{2} \mathrm{pH}_{2} \mathrm{O}$. The combination of an endothermic effect with an extremum at $167.8^{\circ} \mathrm{C}$ and an exothermic effect with a peak at $647.2^{\circ} \mathrm{C}$ is a manifestation of the $\mathrm{SiO}_{2} \mathrm{nH}_{2} \mathrm{O}$ opal phase.

A finely dispersed kaolinite fraction was isolated with the composition by washing with running water for further research, wt\%: $\mathrm{Al}_{2} \mathrm{O}_{3}-31.2 ; \mathrm{SiO}_{2}-51.6 ; \mathrm{Fe}_{2} \mathrm{O}_{3}-0.53 ; \mathrm{CaO}-0.43 ; \mathrm{Na}_{2} \mathrm{O}-0.095 ; \mathrm{MgO}-0.2$; 
$\mathrm{SO}_{3}-0.02 ; \mathrm{K}_{2} \mathrm{O}-1.5 ; \mathrm{TiO}_{2} 1.05 ; \mathrm{Cl}-0.02 ; \mathrm{LOI} 13,355 ; \mu_{\mathrm{si}}-0.6$. The phase composition of the kaolinite fraction: kaolinite $-63.2 \%$, quartz $-21.6 \%$, muscovite $-15.3 \%$. The fraction yield was $41.4 \%$.

The chemical composition of the separated coarse quartz fraction, wt\%: $\mathrm{Al}_{2} \mathrm{O}_{3}-7.65 ; \mathrm{SiO}_{2}-65.5$; $\mathrm{Fe}_{2} \mathrm{O}_{3}-0.68 ; \mathrm{CaO}-0.29 ; \mathrm{Na}_{2} \mathrm{O}-0.031 ; \mathrm{MgO}-0.08 ; \mathrm{SO}_{3}-0.05 ; \mathrm{K}_{2} \mathrm{O}-0.39 ; \mathrm{TiO}_{2}-0.9 ; \mathrm{Cl}-0.016 ; \mathrm{LOI} 24.413$; $\mu_{\mathrm{si}}-0.12$.

The optimal conditions for carrying out the preliminary chemical activation of kaolinite clay were determined for studies of the dependence of the yield of the kaolinite fraction on temperature, duration, $\mathrm{S}: \mathrm{L}$ ratio, and concentration of sodium hydro carbonate solution.

When studying the dependence of the yield of the kaolinite fraction on the temperature of chemical activation, the maximum yield of $79.36 \%$ was obtained at a temperature of $150^{\circ} \mathrm{C}$ (Figure 1 ).

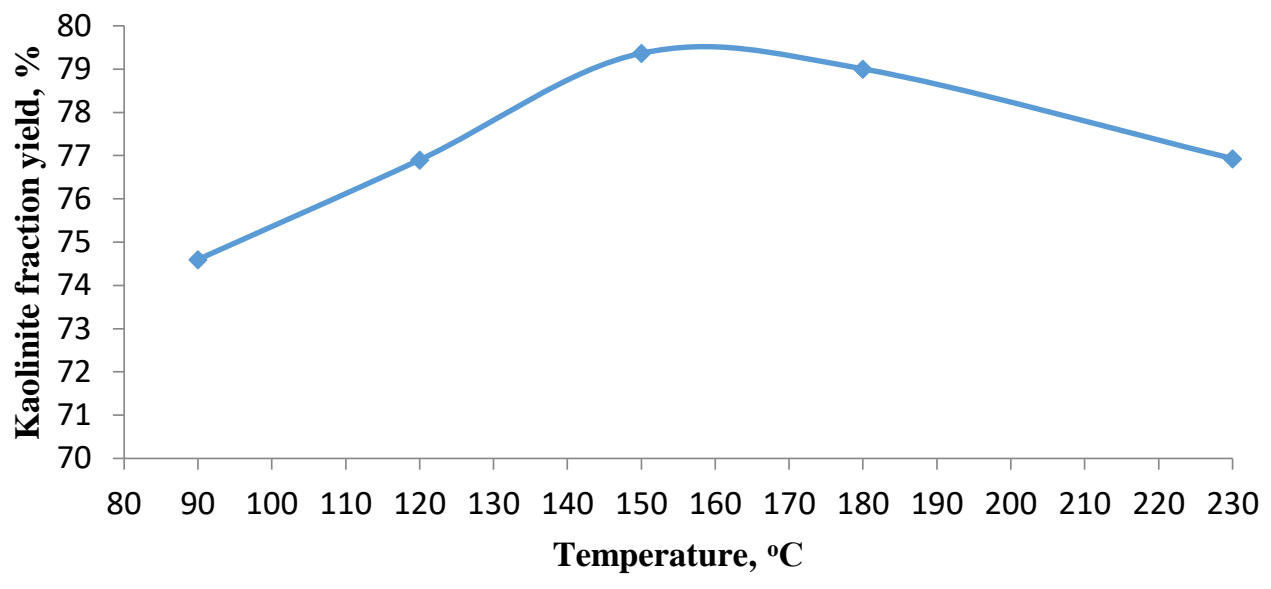

Figure 1. Dependence of the kaolinite fraction yield on the temperature of chemical activation

During chemical activation, changes in the phase composition took place, the content of muscovite decreased almost twofold, and a sodium aluminosilicate phase was formed.

The phase composition of the kaolinite fraction samples depending on the temperature of chemical activation is presented in Table 1.

Table 1. The phase composition of kaolinite fraction samples depending on the temperature of chemical activation

\begin{tabular}{|c|c|c|c|c|c|c|}
\hline \multirow{3}{*}{ Name } & \multicolumn{6}{|c|}{ Content, \% } \\
\hline & \multicolumn{6}{|c|}{ Activation temperature, ${ }^{\circ} \mathrm{C}$} \\
\hline & Ref. & 90 & 120 & 150 & 180 & 230 \\
\hline Kaolinite-1A & 63.2 & 52.9 & 52.1 & 57.0 & 56.3 & 54.8 \\
\hline \multicolumn{7}{|l|}{$\mathrm{AL}_{2} \mathrm{Si}_{2} \mathrm{O}_{5}(\mathrm{OH})_{4}$} \\
\hline Quartz $\mathrm{SiO}_{2}$ & 21.6 & 29.9 & 31.0 & 25.4 & 26.7 & 28.0 \\
\hline Muscovite - 1M & 15.3 & 8.0 & 8.0 & 8.9 & 8.1 & 8.0 \\
\hline \multicolumn{7}{|l|}{$\mathrm{KMgAISi}_{4} \mathrm{O}_{10}(\mathrm{OH})_{2}$} \\
\hline Sodium aluminosilicate & - & 5.8 & 5.2 & 4.9 & 5.2 & 5.5 \\
\hline \multicolumn{7}{|l|}{$\mathrm{Na}_{2} \mathrm{Al}_{1.1} \mathrm{Si}_{94.9} \mathrm{O}_{192}$} \\
\hline Magnetite & - & 3.5 & 3.7 & 3.7 & 3.6 & 3.7 \\
\hline $\mathrm{Fe}\left(\left(\mathrm{Fe}_{1.538} \mathrm{Ti}_{0.462}\right) \mathrm{O}_{4}\right)$ & & & & & & \\
\hline
\end{tabular}

When the dependence of the yield of kaolinite fraction on the duration of chemical activation is studied, it was found that the optimal duration is 120 minutes (Figure 2). A further increase in the duration of activation causes a slight increase in the yield of the kaolinite fraction. 


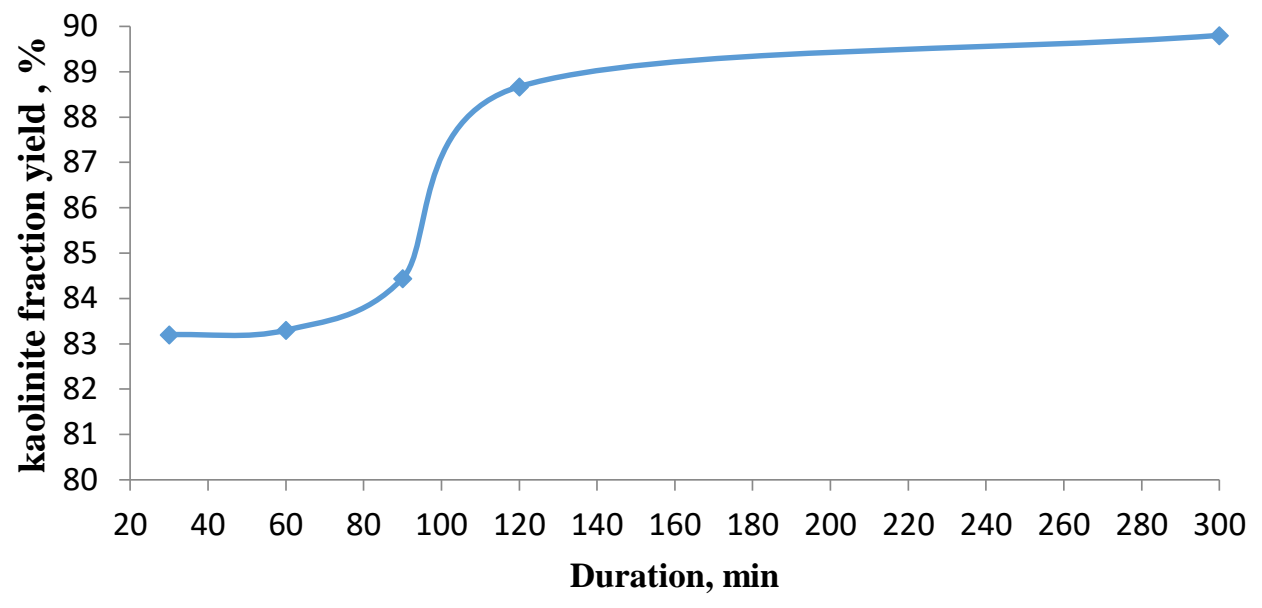

Figure 2. Dependence of the kaolinite fraction yield on the duration of chemical activation

The phase composition of the kaolinite fraction samples depending on the duration of chemical activation is presented in Table 2.

Table 2. The phase composition of kaolinite fraction samples depending on the duration of chemical activation

\begin{tabular}{|c|c|c|c|c|c|c|}
\hline \multirow[t]{3}{*}{ Name } & \multicolumn{6}{|c|}{ Content, \% } \\
\hline & \multicolumn{6}{|c|}{ Duration, $\min$} \\
\hline & Ref. & 30 & 60 & 90 & 120 & 300 \\
\hline $\begin{array}{l}\text { Kaolinite-1A } \\
\mathrm{AL}_{2} \mathrm{Si}_{2} \mathrm{O}_{5}(\mathrm{OH})_{4}\end{array}$ & 63.2 & 62.8 & 62.1 & 61.3 & 63.0 & 64.9 \\
\hline Quartz $\mathrm{SiO}_{2}$ & 21.6 & 24.3 & 28.5 & 28.3 & 28.0 & 26.3 \\
\hline $\begin{array}{l}\text { Muscovite - 1M } \\
\mathrm{KMgAISi}_{4} \mathrm{O}_{10}(\mathrm{OH})_{2}\end{array}$ & 15.3 & 5.5 & 5.1 & 4.4 & 3.8 & 3.7 \\
\hline $\begin{array}{l}\text { Sodium aluminosilicate } \\
\mathrm{Na}_{2} \mathrm{Al}_{1.1} \mathrm{Si}_{94.9 \mathrm{O}_{192}}\end{array}$ & - & 4.2 & 4.0 & 3.8 & 3.3 & 3.1 \\
\hline $\begin{array}{l}\text { Magnetite } \\
\mathrm{Fe}\left(\left(\mathrm{Fe}_{1.538} \mathrm{Ti}_{0.462}\right) \mathrm{O}_{4}\right)\end{array}$ & - & 3.1 & 2.4 & 2.2 & 1.9 & 2.0 \\
\hline
\end{tabular}

In the studies, it was determined that the yield of the kaolinite fraction practically does not depend on the S:L ratio during chemical activation, therefore, it must be selected taking into account the performance of the equipment (Figure 3).

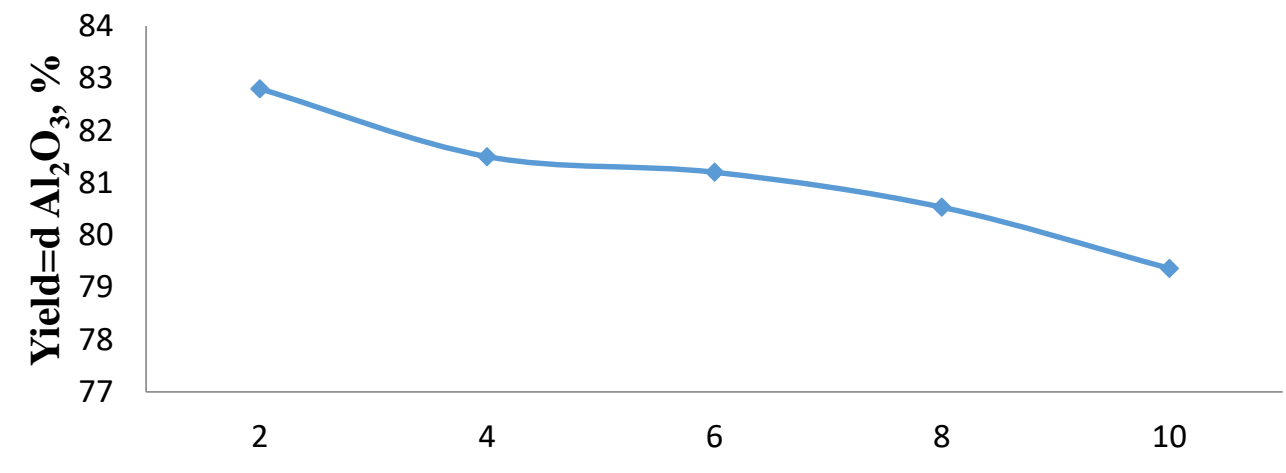

\section{$\mathbf{L}: \mathbf{S}$}

Figure 3. Dependence of the $\mathrm{Al}_{2} \mathrm{O}_{3}$ yield in the kaolinite fraction on the $\mathrm{S}: \mathrm{L}$ ratio of chemical activation 
The phase composition of the kaolinite fraction samples depending on the S:L ratio of chemical activation is presented in Table 3.

Table 3. The phase composition of kaolinite fraction samples depending on the S:L ratio of chemical activation

\begin{tabular}{|c|c|c|c|c|c|c|}
\hline \multirow[t]{3}{*}{ Name } & \multicolumn{6}{|c|}{ Content, \% } \\
\hline & \multicolumn{6}{|c|}{ S:L ratio } \\
\hline & No ref. & $2: 1$ & $4: 1$ & $6: 1$ & $8: 1$ & 10:1 \\
\hline $\begin{array}{l}\text { Kaolinite-1A } \\
\mathrm{AL}_{2} \mathrm{Si}_{2} \mathrm{O}_{5}(\mathrm{OH})_{4}\end{array}$ & 63.2 & 63.1 & 62.6 & 62.5 & 60.4 & 60.1 \\
\hline Quartz $\mathrm{SiO}_{2}$ & 21.6 & 29.5 & 27.3 & 25.7 & 27.2 & 26.9 \\
\hline $\begin{array}{l}\text { Muscovite - 1M } \\
\mathrm{KMgAISi}_{4} \mathrm{O}_{10}(\mathrm{OH})_{2}\end{array}$ & 15.3 & 3.8 & 4.2 & 5.6 & 5.5 & 5.4 \\
\hline $\begin{array}{l}\text { Sodium aluminosilicate } \\
\mathrm{Na}_{2} \mathrm{Al}_{1.1} \mathrm{Si}_{94.9} \mathrm{O}_{192}\end{array}$ & - & 2.3 & 3.7 & 3.8 & 4.3 & 4.9 \\
\hline $\begin{array}{l}\text { Magnetite } \\
\mathrm{Fe}\left(\left(\mathrm{Fe}_{1.538} \mathrm{Ti}_{0.462}\right) \mathrm{O}_{4}\right)\end{array}$ & - & 1.3 & 2.3 & 2.5 & 2.6 & 2.7 \\
\hline
\end{tabular}

Studies of the dependence of the yield of the kaolinite fraction of clay on the concentration of sodium hydro carbonate solution during chemical activation were carried out at a temperature of $150{ }^{\circ} \mathrm{C}$ at a duration of 120 minutes and a S:L ratio $=10: 1$ (Figure 4).

As a result of research, it was found that the yield of the kaolinite fraction increases with an increase in the concentration of sodium hydro carbonate solution.

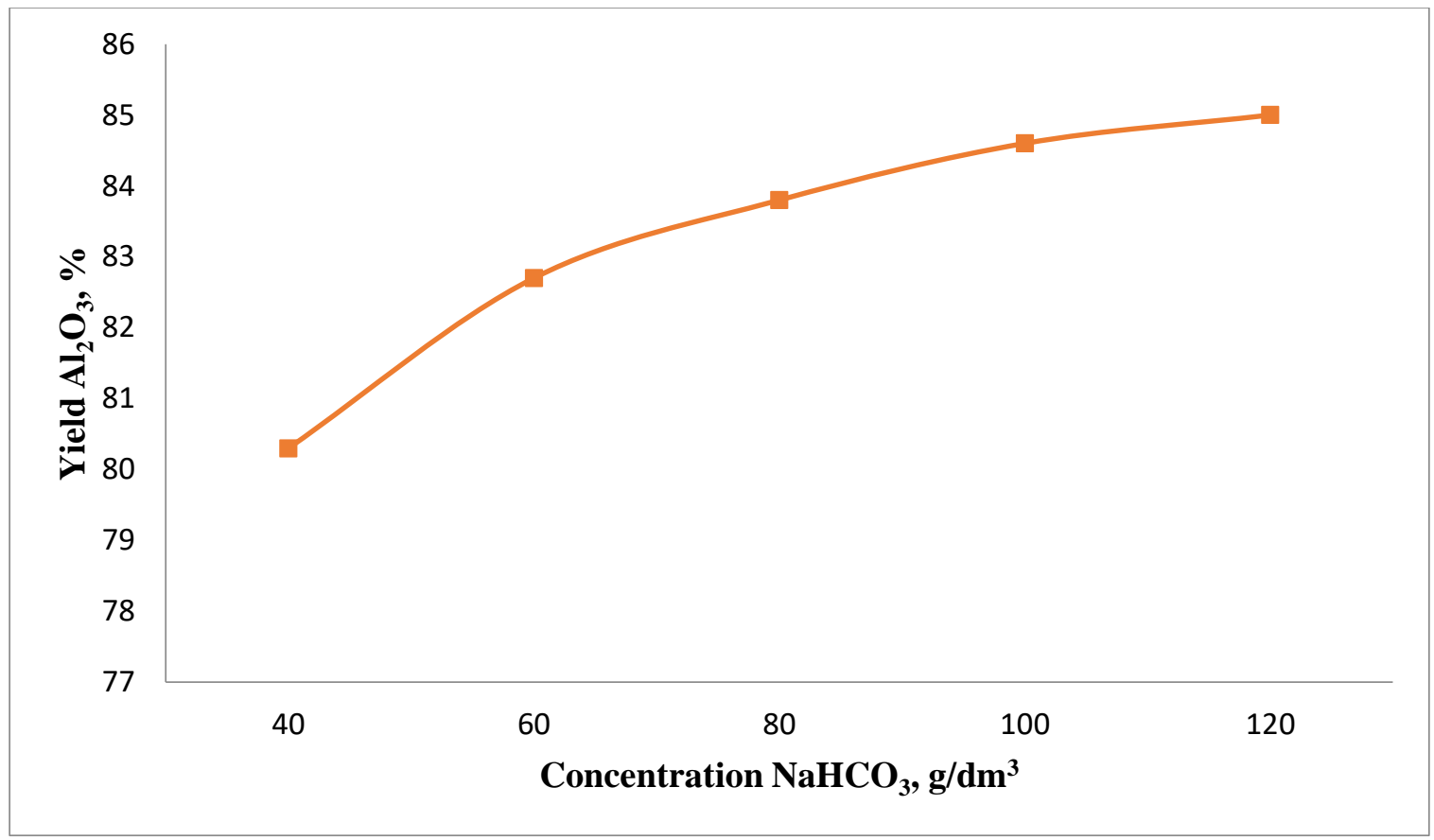

Figure 4. Dependence of the $\mathrm{Al}_{2} \mathrm{O}_{3}$ yield into the kaolinite fraction on the concentration of sodium hydro carbonate solution during chemical activation

The phase composition of the kaolinite fraction samples depending on the concentration of sodium hydro carbonate solution during chemical activation is presented in Table 4. 
Table 4. The phase composition of kaolinite fraction samples depending on the concentration of sodium hydro carbonate solution during chemical activation

\begin{tabular}{|c|c|c|c|c|c|c|}
\hline \multirow[t]{3}{*}{ Name } & \multicolumn{6}{|c|}{ Content, \% } \\
\hline & \multicolumn{6}{|c|}{$\mathrm{NaHCO}_{3}, \mathrm{~g} / \mathrm{dm}^{3}$} \\
\hline & No ref. & 40 & 60 & 80 & 100 & 120 \\
\hline $\begin{array}{l}\text { Kaolinite-1A } \\
\mathrm{AL}_{2} \mathrm{Si}_{2} \mathrm{O}_{5}(\mathrm{OH})_{4}\end{array}$ & 63.2 & 62.2 & 63.6 & 62.1 & 65.7 & 65.0 \\
\hline Quartz $\mathrm{SiO}_{2}$ & 21.6 & 28.9 & 26.1 & 26.2 & 24.8 & 24.6 \\
\hline $\begin{array}{l}\text { Muscovite - 1M } \\
\mathrm{KMgAISi}_{4} \mathrm{O}_{10}(\mathrm{OH})_{2}\end{array}$ & 15.3 & 3.8 & 4.1 & 5.4 & 4.1 & 4.0 \\
\hline $\begin{array}{l}\text { Sodium aluminosilicate } \\
\mathrm{Na}_{2} \mathrm{Al}_{1.1} \mathrm{Si}_{94.9 \mathrm{O}_{192}}\end{array}$ & - & 3.2 & 3.7 & 3.9 & 3.4 & 3.5 \\
\hline $\begin{array}{l}\text { Magnetite } \\
\mathrm{Fe}\left(\left(\mathrm{Fe}_{1.538} \mathrm{Ti}_{0.462}\right) \mathrm{O}_{4}\right)\end{array}$ & - & 2.0 & 2.2 & 2.5 & 2.0 & 2.2 \\
\hline
\end{tabular}

Based on the results obtained, a technology for the complex processing of kaolinite clays has been developed, which provides for the preliminary chemical activation of the feedstock at the beginning of the process, which will effectively isolate high-quality kaolinite and quartz products, which will significantly reduce the flow of materials entering for sintering (Figure 5).

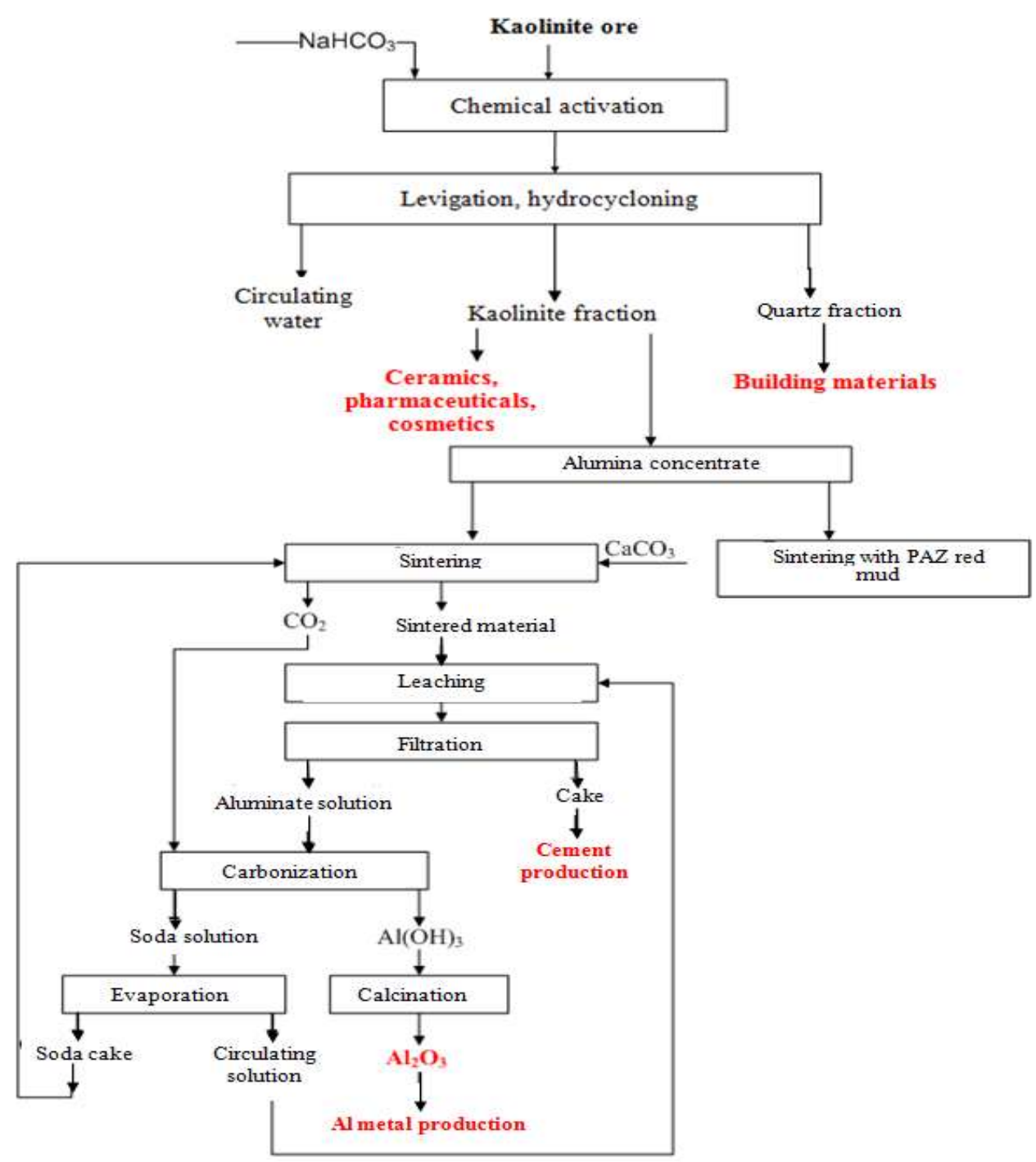

Figure 5. Process flow scheme of complex processing of kaolinite ore 
Conclusions. Research has been carried out on the effect of preliminary chemical activation of kaolinite clays of the Alekseevskiy deposit in a sodium hydro carbonate solution on the separation of kaolinite and quartz fractions. The optimal mode of activation should be considered a temperature of 150 ${ }^{\circ} \mathrm{C}$, a duration of 120 minutes, and a concentration of sodium hydro carbonate solution of $120 \mathrm{~g} / \mathrm{dm}^{3}$.

As a result of activation, the phase composition of the kaolinite fraction has changed: the percentage of the kaolinite fraction has decreased; new phases of muscovite and sodium aluminosilicate appeared; the amount of quartz increased.

The process flow scheme of the complex processing of kaolinite ore has been developed.

\section{Acknowledgments}

This work was based on grant financing \# AR09259345 and supported by the Committee of Science of the Ministry of Education and Science of the Republic of Kazakhstan

Cite this article as: Dyussenova S.; El-Amir, Ahmed A. M. (2021). Research and development of a comprehensive technology for processing kaolinite clays in Kazakhstan. Challenges of Science. Issue IV, 2021, pp. 48-54. https://doi.org/10.31643/2021.07

\section{References}

[1] Kovzalenko V. A., Sarsenbay G., Sadykov N. M.-K., Imangalieva L. M. Kaolins - substandard aluminosilicate raw materials // Complex use of mineral raw materials. - 2015. - No. 3. - pp. 32-37. http://kims-imio.kz/wpcontent/uploads/2018/03/kims-34-39.pdf (in Russ.).

[2] Kenzhaliev B. K., Kuldeev E. I., Abdulvaliyev R. A., Pozmogov V. A., Beisembekova K. O., Gladyshev S. V., Tastanov E. A. Prospects for the development of the aluminum industry in Kazakhstan // Izvestia of the National Academy of Sciences of the Republic of Kazakhstan. Series of Geology and Technical Sciences, No. 3, 2017. - pp. 151-160. ISSN 2224-5278. http://nblib.library.kz/elib/library.kz/jurnal/Geologya\%2003-2017/16\%20Kenzhaliyev\%20Kuldeyev.pdf (in Eng.).

[3] Ibragimov A. T., Budon S. V. Development of technology for the production of alumina from bauxite in KazakhstanPavlodar: "House of Printing" LLP, - 2010. - 299 p. ISBN 978-601-7112-22-6. https://www.twirpx.com/file/2213812/ (in Russ.).

[4] Brichkin V. N., Kurtenkov R. V., Eldib A. B., Bormotov I. S. Aluminum-containing raw materials of Egypt and prospects for its complex processing to obtain alumina and associated products / / XXV Conference "Aluminum of Siberia". Section 1. Production of alumina. - St. Petersburg Mining University, Russia, St. Petersburg. - 2019. p. $173-181$. https://elibrary.ru/item.asp?id=42503942 (in Russ.).

[5] Brichkin V. N., Kurtenkov R. V., Eldib A. B., Bormotov I. S. Conditions and ways of development of the raw material base of aluminum in non-toxic regions// Ore dressing No. 4 - -2019 -St. Petersburg. pp. 31-37. https://doi.org/10.17580/or.2019.04.06 (in Russ.).

[6] Al-Ajeel A.A., Abdullah S.Z., Muslim W.A., Abdulkhader M.Q., Al-Halbosy M.K., Al-Jumely F.A. Extraction of alumina from Iraqi colored kaolin by lime-sinter process // Iraqi Bull. Geol. Min. 2014. Vol. 10, No. 3. P. 109 - 117. http://ibgmiq.org/ibgm/index.php/ibgm/article/view/288 (in Eng.).

[7] Al-Zahrani A.A., Abdul - Majid M.H. Extraction of alumina from local clays by hydrochloric acid process // JKAU: Eng. Sci. 2009. Vol. 20, No. 2. P. $29-41$. https://doi.org/10.4197/ENG.20-2.2 (in Eng.)

[8] Suss A.G., Damaskin A.A., Senyuta A.S., Panov A.V., Smirnov A.A. The influence of the mineral composition of lowgrade aluminum ores on aluminium extraction by acid leaching // Light Metals-2014. Springer International Publishing. P. $105-109$ https://doi.org/10.1007/978-3-319-48144-9_18 (in Eng.).

[9] Wu Y., Li L., Li M. Effect of pressure on alumina extraction from low-grade bauxite by acid-leaching method // Light Metals-2014. Springer International Publishing. P. 121 -123. https://doi.org/10.1007/978-3-319-48144-9_21 (in Eng.).

[10] Sizyakov V. M. Chemical and technological regularities of the processes of sintering of alkaline aluminosilicates and hydrochemical processing of sinters. Notes of the Mining Institute, 2016. Vol. 217. - pp. 102-112. ISSN 0135-3500. 3. https://e.lanbook.com/journal/issue/308555 (in Russ.). 